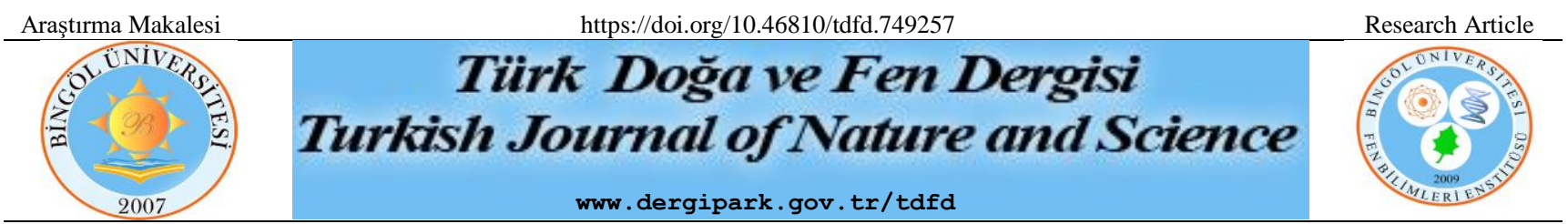

\title{
TBDY 2018 Basitleştirilmiş Tasarım Kurallarının Taban Kesme Kuvvetine Etkisinin İncelenmesi
}

\author{
Bilal BALUN ${ }^{1 *}$, Ömer Faruk NEMUTLU ${ }^{2}$, Ali SARI ${ }^{3}$ \\ ${ }^{1}$ Bingöl Üniversitesi, Enerji, Çevre ve Doğal Afet Çalışmaları Uygulama ve Araştırma Merkezi, Mimarlık Bölümü, \\ Bingöl, Türkiye \\ ${ }^{2}$ Bingöl Üniversitesi, Enerji, Çevre ve Doğal Afet Çalışmaları Uygulama ve Araştırma Merkezi, İnşaat Mühendisliği \\ Bölümü, Bingöl, Türkiye \\ ${ }^{3}$ İstanbul Teknik Üniversitesi, İnşaat Fakültesi İnşaat Mühendisliği Bölümü, İstanbul, Türkiye \\ Bilal BALUN ORCID No: 0000-0003-0906-4484 \\ Ömer Faruk NEMUTLU ORCID No: 0000-0001-7841-3911
}

Ali SARI ORCID No: 0000-0002-6888-1276

*Sorumlu yazar: bbalun@bingol.edu.tr

(Alınış: 08.06.2020, Kabul: 15.10.2020, Online Yayınlanma: 23.10.2020)

Anahtar
Kelimeler
TBDY 2018,
DBYBHY
2007,
Deprem
tasarım sınıfı,
Taban kesme
kuvveti,
Basitleştirilmiş
tasarım
kuralları

Anahtar

meler

DBYBHY

2007

Taban kesme

kuvveti,

kuralları

\begin{abstract}
Öz: Depremlerin yıkıcı etkileri deprem tasarım kurallarını içeren yönetmeliklerin kullanılmasını zorunlu kılmaktadır. Geçmişten günümüze ülkemizde can ve mal kaybına sebep olan birçok deprem meydana gelmiştir. Deprem yönetmelikleri depremlerin yıkıcı etkilerini azaltmak için kullanılırken günümüz tasarım anlayışına da cevap vermelidir. 2018 yılında yürürlüğe giren Türkiye Bina Deprem Yönetmeliği (TBDY 2018), 2007 Deprem Bölgelerinde Yapılacak Binalar Hakkında Yönetmeliğine (DBYBHY 2007) göre içerik ve kapsam bakımından değişikliğe uğramıştır. 2018 deprem yönetmeliğine eklenen bölümlerden biri de düzenli yerinde dökme betonarme binalar için basitleştirilmiş tasarım kurallarıdır. Bu bölüme göre belirli tasarım sınırları içerisinde kalma koşuluyla, basitleştirilmiş hesap esasları kullanılarak yapıların deprem karşı tasarımları karmaşıklıktan sıyrılmaktadır. Bu çalışmada TBDY 2018 bölüm 17'de belirtilen iki farklı deprem tasarım sınıfı için basitleştirilmiş ve standart hesap yöntemlerine göre belirlenen bir yapının taban kesme kuvvetleri ETABS v18 programı kullanılarak karşılaştırılmıştır. Yerel zemin sınıfları ve bina yüksekliği bu bölümün sınırları içerisinde kalacak şekilde değişken olarak belirlenmiştir. Yapılan analizler sonucunda deprem tasarım sınıfının, yerel zemin sınıfının ve yapının kat sayısının basitleştirilmiş deprem hesabı ile standart deprem hesabı arasında fark oluşturduğu ortaya çıkmıştır. Genel olarak basitleştirilmiş hesaptan elde edilen taban kesme kuvvetleri standart yöntem ile elde edilen taban kesme kuvvetlerinden daha büyük değerler elde etmiştir.
\end{abstract}

\section{Investigation of the Effect of TEC 2018 Simplified Design Rules on Base Shear Force}

Keywords TEC 2018, TEC 2007, Earthquake design class, Base shear force, Simplified design rules

\begin{abstract}
The destructive effects of earthquakes necessitate the use of codes that include earthquake design rules. Many earthquakes that caused loss of life and property have occurred in Turkey from past to present. While earthquake codes are used to reduce the destructive effects of earthquakes, they should also respond to today's design approach. 2018 Turkey Earthquake Building Codes (TEC 2018) has changed the content and scope according to the 2007 earthquake codes (TEC 2007). One of the sections added to the 2018 earthquake code is the simplified design rules for regular on-site cast reinforced concrete buildings. According to this section, using the simplified calculation principles, the earthquake-resistant designs of the buildings stand out from the complexity, provided that they remain within certain design limits. In this study, the base shear forces of a building determined according to standard calculation methods are compared for two different earthquake design classes specified in TEC 2018 part 17 by ETABS v18 software. Local floor classes and building height have been determined as variables to be within the boundaries of this section. As a result of the analysis, it was revealed that the earthquake design class, the local ground class and the number of floors of the building make a difference between the simplified earthquake calculation and the standard earthquake calculation. In general, the base shear forces obtained from the simplified calculation have obtained greater values than the base shear forces obtained by the standard method.
\end{abstract}




\section{GíRIŞ}

Depremler can ve mal kayıplarına yol açabilecek doğal afetlerden olup ülkemiz sismik aktivitelerden ötürü geçmiş yıllarda bu gerçeklerle karşılaşmak durumunda kalmıştır. Türkiye, dünyadaki en önemli deprem kuşaklarının (Alp-Himalaya veya Akdeniz çevresi deprem kuşağı) bulunduğu bölgede yer alırken geçmişte meydana gelen yıkıcı depremler ülkemizdeki deprem tehlikesini ortaya koymaktadır [1]. Depremler genellikle yer kabuğunun hareketleri sonucunda oluşmaktayken fayın özellikleri ve zemin durumu gibi parametreler depremlerin yıkıcılığını etkilemektedir. Bunun yanında depreme dayanıklı tasarım ilkeleriyle inşa edilmeyen yapılar ciddi can ve mal kayıplarına sebep olabilmektedir [2,3]. Bu amaçla depreme dayanıklı tasarım için yönetmelikler oluşturulmuştur. Türkiye'de 1940'tan 2018'e kadar belirli zaman aralıklarında deprem yönetmelikleri yürürlüğe girmiştir $[2,4,5]$. En güncel deprem yönetmeliğimiz 2018 yılında yürürlüğe giren Türkiye Bina Deprem Yönetmeliğidir (TBDY 2018) [6] ve 2007 Deprem Bölgelerinde Yapılacak Binalar Hakkındaki Yönetmeliğin (DBYBHY 2007) [7] yerini almıştır. 2007 deprem yönetmeliği küçük çaplı değişiklikler dışında 1998 deprem yönetmeliği [8] ile benzerlik göstermektedir. 2018 deprem yönetmeliği uzun bir sürenin sonunda yenilenirken bir önceki deprem yönetmeliğimiz depreme dayanıklı tasarım açısından günümüz mühendislik alanındaki gelişmelerden uzak kalmıştır [9].

TBDY 2018'de deprem bölgeleri kavramı yerine deprem tasarım sınıfları kullanılmış ve deprem yer hareketleri tehlike haritaları ile tanımlanmıştır (Şekil 1) [10,11]. Koordinata dayalı deprem verilerinin paylaşıldığı Türkiye Deprem Tehlike Haritalarına interaktif web uygulaması üzerinden erişilebilmektedir [12]. Etkin yer ivmesi kavramının yerini, kısa ve 1,0 periyotlara karş1lık gelen ivmeler almıştır.

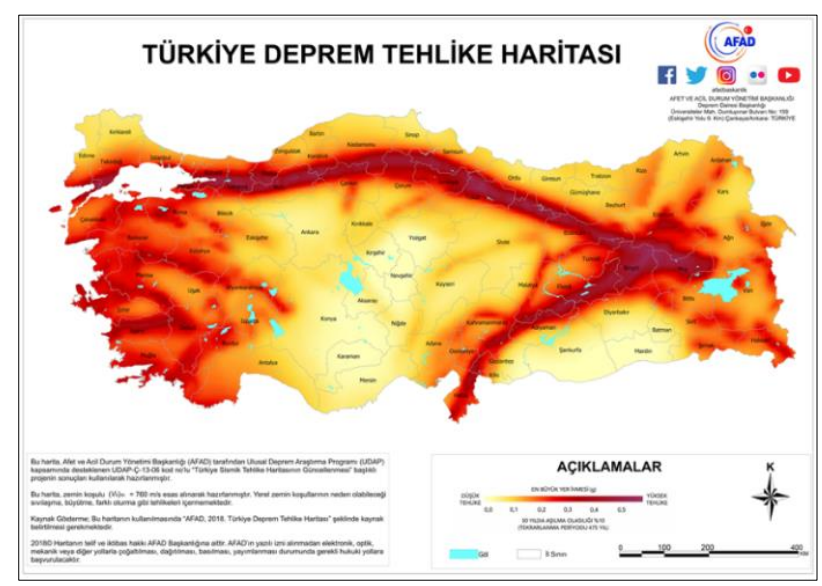

Şekil 1. Türkiye deprem tehlike haritası [11]

TBDY 2018'in, 2007 deprem yönetmeliğine göre kapsamı genişlemiş ve yönetmelikte birtakım iyileştirmeler yapılmıştır. Ön üretimli betonarme, hafif çelik, ahşap ve yüksek binalar hakkında depreme dayanıklı tasarım kuralları ilave olarak verilmiştir. Ayrıca depreme dayanıklı yapı tasarımı açısından günümüzde önem kazanan deprem etkisi altında yalıtımlı binalar da ayrı bir bölüm olarak yönetmelikte yer almıştır. Bunların yanında bu çalışmanın da konusu olan TBDY 2018 bölüm 17'de düzenli yerinde dökme betonarme binalar için basitleştirilmiş tasarım kuralları ele alınmıştır. Bu bölüm sadece Bina Kullanım Sınıfı (BKS) 3 olan (konutlar, işyerleri, oteller, bina türü endüstri yapıları, vb.) betonarme binalar için geçerli olup basitleştirilmiş hesabın uygulanabileceği yapıları boyutsal olarak sınırlandırmıştır. Bunun yanında bu kurallar çerçevesinde kalan yapılarda kullanılabilecek malzemeler ve Bina Yükseklik Sınıfları (BYS) belirlenmiştir.

Bazı çalışmalarda depreme dayanıklı tasarım hesap yöntemleri incelenirken birçok çalışmada da TBDY 2018 ile DBYBHY 2007 arasındaki farklılıklar incelenmiştir [2,3,9,13-17]. Farklı zemin sınıflarının yapıların depreme karşı davranışına etkisinin incelendiği çalışmalar da literatürde mevcuttur $[3,18]$. Keskin ve Bozdoğan [3] yaptığı çalışmada, 2018 Türk deprem yönetmeliğine göre zemin sinıflarının taban kesme kuvvetlerine etkisini incelemiştir. Elde edilen sonuçlara göre yerel zemin sınıflarının taban kesme kuvvetlerini etkilediği tespit edilmiştir. TBDY 2018 bölüm 17'nin incelenmesi basitleştirilmiş tasarım kurallarının anlaşılmasına ve uygulamada yaşanabilecek sorunların ortadan kalkmasına yardımcı olacaktır. Deprem yönetmelikleri yürürlüğe girdikten sonra tasarım kurallarının anlaşılması ve tam anlamıyla hayata geçmesi biraz zaman alabilmektedir. Bu sebeple yapılacak olan literatür çalışmaları ve bilimsel toplantılar yönetmeliklerin daha iyi kavranmasına katkıda

Bu çalışmanın amacı, TBDY 2018 yönetmeliğinde yer alan standart deprem yer hareketi spektrumu kullanılarak elde edilen taban kesme kuvvetleri ile bölüm 17'de tanımlanan basitleştirilmiş tasarım kurallarına göre elde edilen taban kesme kuvvetlerini, yönetmeliğin izin verdiği sınırlar içerisinde karşılaştırmaktır. Elde edilecek sonuçlar basitleştirilmiş hesabın elverişli ya da elverişsiz durumlarını belirlemeye 1 şık tutacaktır.

\section{YÖNTEM}

Bu çalışmada, aşağıda kat planı ve görünüşü (Şekil 2 ve 3) verilen yerinde dökme betonarme yapının, TBDY 2018'de yer alan 17. bölüm (Düzenli Yerinde Dökme Betonarme Binalar İçin Basitleştirilmiş Tasarım Kuralları) ve yine aynı yönetmelikte yer alan standart deprem yer hareketi spektrumuna göre eşdeğer deprem yükü analizleri sonlu eleman tabanlı bir program olan ETABS v18 ile gerçekleştirilmiş ve taban kesme kuvvetleri karşılaştırılmıştır. Bu amaçla aşağıda verilen plan, 17. bölümün genel kuralları içerisinde kalacak şekilde tasarlanmıştır. TBDY 2018 bölüm 17 ile standart deprem yer hareket düzeyine göre gerçekleştirilen deprem analiz sonuçlarını kıyaslamak için iki farklı deprem tasarım sınıfı (DTS=1, 2 ve DTS=3, 4), 3 farklı kat sayısı (3, 4 ve 5 kat) ve 5 farklı zemin sinıfi (ZA, ZB, ZC, ZD ve ZE) kullanılmıştır. TBDY 2018'de belirtilen ve en kötü zeminleri ifade eden $Z F$ yerel zemin sınıfi, sahaya özel davranış analizi gerektirdiği için 
hesaplamalarda dikkate alınmamıştır [19]. Yapıların yüksekliği depreme dayanıklı yapı tasarımı açısından dikkate alınması gereken bir unsur olduğundan dolayı farklı kat sayıları belirlenmiştir [19]. Yapının kat sayılarının yukarıda belirtildiği gibi olmasının nedeni 17 . Bölümde $\mathrm{DTS}=1,2$ için $\mathrm{BYS} \geq 5$ ve $\mathrm{DTS}=3,4$ için $\mathrm{BYS} \geq 6$ olacak şekilde bina yüksekliklerinin sınırlandırılmış olmasından kaynaklanmaktadır (Tablo $1)$.

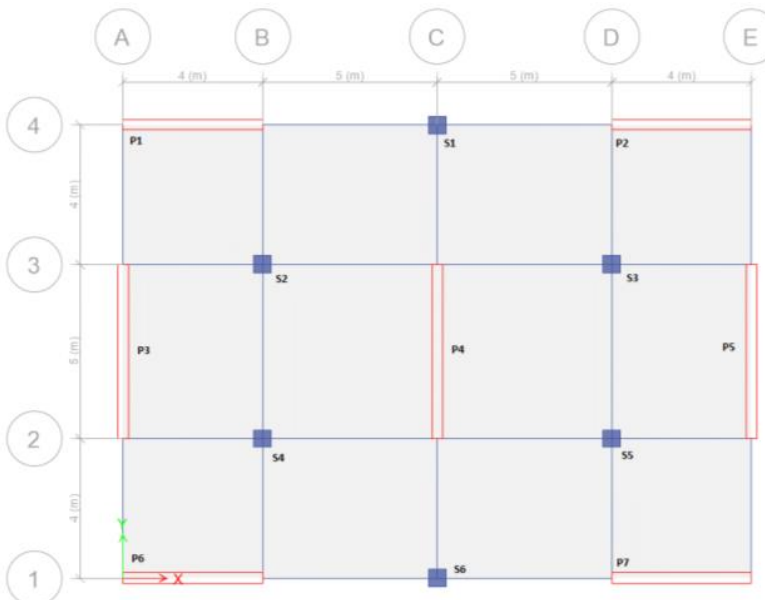

Şekil 2. Kat planı

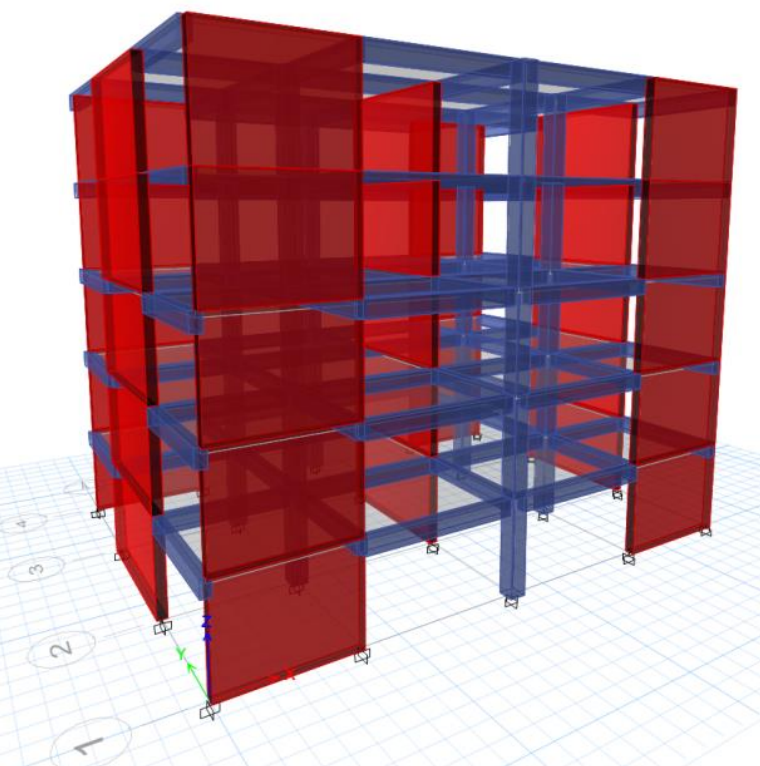

Şekil 3. Yapının perspektif görünüşü

Tablo 1. BYS ve deprem tasarım sinıflarına göre tanımlanan bina yükseklik aralıkları [6]

\begin{tabular}{|c|c|c|c|}
\hline \multirow{2}{*}{$\begin{array}{c}\text { Bina } \\
\text { Yükseklik Sinıfi }\end{array}$} & \multicolumn{3}{|c|}{$\begin{array}{c}\text { Bina Yükseklik Smıfları ve Deprem Tasarmm Sumflarma Göre } \\
\text { Tanmlanan Bina Yükseklik Aralıklan [m] }\end{array}$} \\
\cline { 2 - 4 } & DTS $=1,1 \mathrm{a}, 2,2 \mathrm{a}$ & DTS $=3,3 \mathrm{a}$ & DTS $=4,4 \mathrm{a}$ \\
\hline BYS $=1$ & $H_{\mathrm{N}}>70$ & $H_{\mathrm{N}}>91$ & $H_{\mathrm{N}}>105$ \\
\hline BYS $=2$ & $56<H_{\mathrm{N}} \leq 70$ & $70<H_{\mathrm{N}} \leq 91$ & $91<H_{\mathrm{N}} \leq 105$ \\
\hline BYS $=3$ & $42<H_{\mathrm{N}} \leq 56$ & $56<H_{\mathrm{N}} \leq 70$ & $56<H_{\mathrm{N}} \leq 91$ \\
\hline BYS $=4$ & $28<H_{\mathrm{N}} \leq 42$ & $42<H_{\mathrm{N}} \leq 56$ \\
\hline BYS $=5$ & $17.5<H_{\mathrm{N}} \leq 28$ & $28<H_{\mathrm{N}} \leq 42$ \\
\hline BYS $=6$ & $10.5<H_{\mathrm{N}} \leq 17.5$ & $17.5<H_{\mathrm{N}} \leq 28$ \\
\hline BYS $=7$ & $7<H_{\mathrm{N}} \leq 10.5$ & $10.5<H_{\mathrm{N}} \leq 17.5$ \\
\hline BYS $=8$ & $H_{\mathrm{N}} \leq 7$ & \multicolumn{2}{|c|}{$H_{\mathrm{N}} \leq 10.5$} \\
\hline
\end{tabular}

Yapının boyutsal tasarımı 17. Bölümün genel kuralları içerisinde kalacak şekilde gerçekleştirilmiştir. TBDY 2018 bölüm $17^{\prime}$ 'de basitleştirilmiş tasarım hesabı yapılacak yapının taşıyıcı sistemi, süneklik düzeyi yüksek çerçevelerden veya süneklik düzeyi yüksek boşluksuz perdeler ile süneklik düzeyi yüksek çerçevelerin birlikte kullanımından oluşması istenmektedir. Tasarımı yapılacak betonarme yapida kullanılacak beton sinifi C25 ile C50 arasında olmalı B420C veya S420 dişında donatı çeliği kullanılmamalıdır. Bu çalışmada C30 betonu ve S420 donatı çeliği kullanılmıştır. Çalışmada yapılan analizlerde tüm örnekler için sabit yük $1.5 \mathrm{kN} / \mathrm{m}^{2}$, hareketli yük ise $2.0 \mathrm{kN} / \mathrm{m}^{2}$ olarak alınmıştır. 17 . Bölümde verilen yük kombinasyonlarında kar yükünün etki ettirildiği durumlarda, en üst kata etki ettirilen deprem yüküne dahil edilebileceği belirtilmiştir. $\mathrm{Bu}$ çalışmada 17. Bölümde verilen kar yükünü içeren kombinasyonlar dikkate alınmadığı için kar yükü analizlerde ihmal edilmiştir. Eğer tasarlanacak yapı DTS=1 ve 2 ise yapıda süneklik düzeyi boşluksuz perde kullanılması zorunludur [6]. Bu çalıșma için seçilen yapıda süneklik düzeyi yüksek boşluksuz perdeler ile süneklik düzeyi yüksek betonarme çerçeve sistemi birlikte kullanılmıştır. TBDY 2018 bölüm 17’ye göre yapı planında uzun kenar 30 m'den, uzun kenarın kısa kenara oranı ise 4'ten fazla olmamalıdır. Çalışmada kullanılan planın uzun kenarı $18 \mathrm{~m}$ iken kısa kenarı 13 m'dir. Bir diğer boyutsal parametre ise yapının açıklıklarının sınırlandırılmasından meydana gelmektedir.

Yapımızın planda en büyük açıklığı 7,5 m en küçük açıklığ 1 ise $3 \mathrm{~m}$ olmak zorundadır. Yapımızın kat yüksekliğinin $4 \mathrm{~m}$ 'den fazla olmaması istendiğinden çalışmaya konu olan binanın kat yüksekliği $3 \mathrm{~m}$ olarak belirlenmiștir. Basitleştirilmiş tasarım esaslarında dikkat edilmesi gereken bir diğer husus ise düzensizliklerdir. Bilindiği üzere TBDHY 2007 ve TBDY 2018'de düzensiz binalar planda (A1, A2 ve A3) ve düşeyde (B1, B2 ve B3) düzensizlik durumlarına göre incelenmektedir. TBDY 2018 bölüm 17'deki basitleştirilmiş tasarım esaslarına göre yerinde dökme betonarme yapının A2 (Döşeme süreksizlikleri), A3 (Planda çıkıntı bulunmaması), B1 (Zayıf kat) ve B3 (Taşıyıcı sistemin düşey elemanlarının süreksizliği) düzensizliklerine sahip olmaması gerekmektedir. $\mathrm{Bu}$ çalışmaya konu olan yapının A2, A3, B1 ve B3 düzensizlikleri bulunmamaktadır.

TBDY 2018 bölüm 17, yerinde dökme betonarme binaların basitleştirilmiş tasarımında düşey taşıyıcı elemanlarının boyutlandırılması için belirli yaklaşımlarda bulunmuştur. Çalışmada kullanılacak yapı süneklik düzeyi yüksek çerçeve ve perdelerden oluştuğu için TBDY 2018 17.3.2 maddesi dikkate alınmıştır. Bu bölüme göre kolonların enkesit alanları, eksenel basınç gerilmeleri ve yeterli kesme dayanımları göz önüne alınacak şekilde sınırlandırılmış ve aşağıda Eşitlik 1 ve Eşitlik 2'de sırasıyla verilmiştir. $\Sigma \mathrm{A}_{0 \mathrm{i}}$, kolonun bütün katlar boyunca alan paylarının toplamını ifade etmektedir. 


$$
\begin{gathered}
A_{c i} \geq 0.00012(g+q) \sum A_{0 i} \\
A_{c i} \geq 0.0001 S_{D S}(g+0,3 q) \sum A_{0 i}
\end{gathered}
$$

Bir diğer düşey taşıyıcı eleman olan perdelerin yeterli kesme dayanımına sahip olması istenmekte ve her iki deprem doğrultusu için toplam perde enkesit alanlarının toplamı $\left(\Sigma \mathrm{A}_{\mathrm{wi}}\right)$ Eşitlik 3 ve 4 'teki koşulu sağlaması gerekmektedir. $\Sigma \mathrm{A}_{\mathrm{pi}}$ bina kat alanlarının toplamını, $\Sigma \mathrm{A}_{\mathrm{pt}}$ ise bina taban alanını temsil etmektedir.

$$
\begin{aligned}
& \sum A_{w i} \geq 0.0002 S_{D S}(g+0,3 q) \sum A_{p i} \\
& \sum A_{w i} \geq 0.0007 S_{D S}(g+0,3 q) \sum A_{p t}
\end{aligned}
$$

TBDY 2018'de yer alan bölüm 17.3'teki hesap esaslarına ve tasarım kurallarına göre çalışmaya konu olan yapının düşey taşıyıcı elemanları eksenel kuvvetler ve kesme dayanımları göz önüne alındığında yeterli enkesit özelliklerine sahip olduğu belirlenmiştir.

TBDY 2018 bölüm 17, taşıyıcı sistem elemanlarının enkesit boyutlarını genel bir değerlendirme ile belirtmiştir. 17. bölümün 17.4 maddesinde kolon, kiriş ve perdelerin enkesit alt sınırları verilmiştir. Buna göre, kolonların en küçük enkesiti $30 \mathrm{~cm} \quad$ x $30 \mathrm{~cm}$ boyutlarından oluşmalıdır. Kirişlerin genişliği en az 30 $\mathrm{cm}$ yüksekliği ise $50 \mathrm{~cm}$ olmalıdır. Perdelerin kalınlığ $25 \mathrm{~cm}$ 'den ve perdenin plandaki uzunluğunun $1 / 25$ 'inden az olmamalıdır. Yine aynı bölümde döşeme kalınlıkları için de sınır değerler verilmiştir. Buna göre, kirişli döşeme plak kalınlığı en az 15 cm olması gerekirken, dişli veya dolgu (asmolen) döşeme plak kalınlığı en az $70 \mathrm{~mm}$ olmalıdır. Çalışmadaki yapı, bütün enkesit koşullarını sağlamaktadır (Tablo 2).

$\mathrm{Bu}$ çalışmada kullanılan tasarım modellerine ait doğal titreşim periyodu ve yapı ağırlıkları Tablo 3'te verilmiştir. Yapının kat adedinin artmasıyla doğal titreşim periyodunun ve yap1 ağırlığının büyüdüğü

\begin{tabular}{|c|c|c|c|}
\hline $\begin{array}{l}\text { Taşıyıcı } \\
\text { eleman }\end{array}$ & $\mathbf{b}_{\mathbf{x}}(\mathbf{c m})$ & $b_{y}(\mathbf{c m})$ & $\begin{array}{c}\text { Sınır değerler } \\
\text { (TBDY } 2018 \text { Bölüm 17) }\end{array}$ \\
\hline S01 & 50 & 50 & \multirow{6}{*}{ En az $30 \mathrm{~cm}$ x $30 \mathrm{~cm}$} \\
\hline S02 & 50 & 50 & \\
\hline S03 & 50 & 50 & \\
\hline S04 & 50 & 50 & \\
\hline S05 & 50 & 50 & \\
\hline S06 & 50 & 50 & \\
\hline P01 & 400 & 25 & \multirow{7}{*}{$\begin{array}{c}\text { Perde kalınlığı } \\
\text { uzunluğunun 1/25'inden } \\
\text { ve } 25 \mathrm{~cm} \text { 'den az olamaz } \\
\text { En küçük perde } \\
\text { uzunluğu > Bina } \\
\text { yüksekliğinin 1/8'i } \\
\text { (Zemin kattan itibaren) }\end{array}$} \\
\hline $\mathrm{P} 02$ & 400 & 25 & \\
\hline $\mathrm{P} 03$ & 25 & 500 & \\
\hline P04 & 25 & 500 & \\
\hline P05 & 25 & 500 & \\
\hline P06 & 400 & 25 & \\
\hline \multirow[t]{2}{*}{$\mathrm{P} 07$} & 400 & 25 & \\
\hline & $\begin{array}{l}\text { Genişlik } \\
\text { (cm) }\end{array}$ & $\begin{array}{l}\text { Yükseklik } \\
(\mathrm{cm})\end{array}$ & \\
\hline Kiriş & 30 & 50 & En az $30 \mathrm{~cm}$ x $50 \mathrm{~cm}$ \\
\hline Döşeme & \multicolumn{2}{|c|}{ Kalınlık (cm) } & $\begin{array}{c}\text { Kirişli plak en az } 15 \mathrm{~cm} \text {, } \\
\text { dişli ve dolgulu döşeme } \\
\text { sistemi plak en az } 70 \\
\text { mm }\end{array}$ \\
\hline
\end{tabular}
görülmektedir.
Tablo 2. Çalıșmaya konu olan binanın tașıyııı elemanlarının enkesit boyutları

Tablo 3. Tasarım modellerinin doğal titreşim periyotları ve yapı ağırlıkları

\begin{tabular}{ccc}
\hline Kat Adedi & Doğal Titreşim Periyodu (sn) & Yapı Ağırlığı (kN) \\
\hline 3 & 0.12 & 7985.52 \\
4 & 0.20 & 10501.05 \\
5 & 0.28 & 13241.83 \\
\hline
\end{tabular}

TBDY 2018 bölüm 17 basitleștirilmiş tasarım esasları kullanılacak yapının inşa edileceği lokasyon, iki farklı deprem tasarım sınıfını temsil edecek şekilde belirlenmiştir. Buna göre, DTS=1, 2 için Bingöl ili (Enlem: $38,898536^{\circ}$, Boylam: 40,488724ํ), DTS=3, 4 için ise Kurşehir ili (Enlem: 39,148505', Boylam: $34,172692^{\circ}$ ) AFAD'ın Türkiye Deprem Tehlike Haritaları interaktif web uygulaması [12] kullanılarak seçilmiştir. Deprem tasarım sınıfları, deprem hareket düzeyi DD-2 (50 yılda aşılma olasılığı $\% 10$ ve tekrarlama periyodu 475 yıl olan depremler) için tanımlanan kisa periyot spektral ivme katsayısı $\left(\mathrm{S}_{\mathrm{DS}}\right)$ ve BKS'ye göre belirlenmektedir. Deprem tasarım sınıfları TBDY 2018 bölüm 3.2'de verilmiştir (Tablo 4) [6].

Tablo 4. Deprem Tasarım Sinıfları (DTS) [6]

\begin{tabular}{|c|c|c|}
\hline \multirow{2}{*}{$\begin{array}{c}\text { DD-2 Deprem Yer Hareketi Düzeyinde Kısa } \\
\text { Periyot Tasarım Spektral İvme Katsayısı }\left(S_{\text {DS }}\right)\end{array}$} & \multicolumn{2}{|c|}{ Bina Kullanım Sınıf } \\
\cline { 2 - 3 } & BKS $=1$ & BKS $=2,3$ \\
\hline$S_{\mathrm{DS}}<0.33$ & DTS $=4 \mathrm{a}$ & DTS $=4$ \\
\hline $0.33 \leq S_{\mathrm{DS}}<0.50$ & $\mathrm{DTS}=3 \mathrm{a}$ & $\mathrm{DTS}=3$ \\
\hline $0.50 \leq S_{\mathrm{DS}}<0.75$ & DTS $=2 \mathrm{a}$ & $\mathrm{DTS}=2$ \\
\hline $0.75 \leq S_{\mathrm{DS}}$ & DTS $=1 \mathrm{a}$ & DTS $=1$ \\
\hline
\end{tabular}

Yapımız daha önceden belirtildiği gibi BYS sınırlandırmalarından ötürü 3,4 ve 5 katlı olarak değerlendirmeye alınmıştır. Yapının plandaki boyutu $18,5 \mathrm{~m}$ ve $11,0 \mathrm{~m}$ 'dir. TBDY 2018 17. bölümdeki basitleştirilmiş tasarım esaslarının sadece $\mathrm{BKS}=3$ sınıfına giren yapılar için uygulanabileceğini belirtmiştir. BYS, TBDY 2018 17. bölümdeki sınırlandırılmalar göz önüne alınarak belirlenmiştir [6]. 5 katlı bina için bina 
yüksekliğimiz, DTS=1, 2 için $\mathrm{BYS} \geq 5$ ve DTS=3, 4 için $\mathrm{BYS} \geq 6$ koşulunu sağlaması gerektiğinden $15 \mathrm{~m}$ olarak seçilmiştir. $\mathrm{DTS}=1,2$ için $\mathrm{BYS}=6$ ve $\mathrm{DTS}=3,4$ için $\mathrm{BYS}=7$ koşulunu sağlaması gerektiğinden, 4 katlı bina için bina yüksekliğimiz $12 \mathrm{~m}$ seçilmiştir. DTS $=1$, 2 için $\mathrm{BYS}=7$ ve $\mathrm{DTS}=3,4$ için $\mathrm{BYS}=8$ koşulunu sağlaması gerektiğinden, 3 katlı bina için bina yüksekliğimiz $9 \mathrm{~m}$ olarak seçilmiştir (Tablo 1).

AFAD'ın Türkiye Deprem Tehlike Haritaları interaktif web uygulaması [12] kullanılarak, kisa ve uzun spektral ivme katsayıları deprem tasarım sınıfları ve yerel zemin sınıflarına göre elde edilmiştir (Tablo 5).

Tablo 5. Kısa ve uzun periyot spektral ivme katsayıları

\begin{tabular}{cccc}
\hline $\begin{array}{c}\text { Deprem Tasarım } \\
\text { Sinıfi }\end{array}$ & $\begin{array}{c}\text { Yerel Zemin } \\
\text { Sinıf }\end{array}$ & $\mathbf{S}_{\mathbf{D S}}$ & $\mathbf{S}_{\text {D1 }}$ \\
\hline & $\mathbf{Z A}$ & 1,281 & 0,336 \\
$\mathbf{D T S}=\mathbf{1 , 2}$ & $\mathbf{Z B}$ & 1,441 & 0,336 \\
& $\mathbf{Z C}$ & 1,921 & 0,630 \\
& $\mathbf{Z D}$ & 1,601 & 0,790 \\
& $\mathbf{Z E}$ & 1,281 & 0,991 \\
\hline $\mathbf{D T S}=\mathbf{3 , 4}$ & $\mathbf{Z A}$ & 0,158 & 0,054 \\
& $\mathbf{Z B}$ & 0,178 & 0,054 \\
& $\mathbf{Z C}$ & 0,257 & 0,102 \\
& $\mathbf{Z D}$ & 0,317 & 0,163 \\
& $\mathbf{Z E}$ & 0,475 & 0,286 \\
\hline
\end{tabular}

TBDY 2018 17. bölümde, basitleştirilmiş yapısal çözümleme için deprem etkilerinin hesabı her bir doğrultu için eş değer deprem yükü yöntemi kullanılarak gerçekleştirilmesi gerektiği belirtilmiştir. TBDY 2018'de standart deprem yer hareketi spektrumuna göre yapılacak hesaplamalarda deprem yükü azaltma katsayıları yapının doğal titreşim periyodu $(T)$ ve $T_{B}$ köşe periyodu dikkate alınarak Eşitlik 5 ve 6'da belirtildiği gibi hesaplanmaktadır.

$$
\begin{gathered}
R_{a}(T)=\frac{R}{I}, \quad T>T_{B} \\
R_{a}(T)=D+\left(\frac{R}{I}-D\right) \frac{T}{T_{B}}, \quad T \leq T_{B}
\end{gathered}
$$

Hesaba katılacak yapının taşıyıcı sistem durumuna, doğal titreşim periyodu ile $T_{B}$ köşe periyodu arasındaki ilişkiye ve dayanım fazlalığı katsayısına göre taşıyıcı sistem davranış katsayısı değişebilmektedir (Eşitlik 5 ve 6). Fakat basitleştirilmiş tasarım esaslarının belirtildiği TBDY 201817 bölümde deprem etkilerinin hesab1 yapılırken deprem yükü azaltma katsayısının $\left(R_{a}\right) 4$ alınması zorunludur. Bu kavrama göre, basitleştirilmiş hesapta yapımızın standart deprem yer hareketi spektrumuna göre daha fazla deprem kuvvetleri alması beklenmektedir. Basitleştirilmiş hesaba göre, binaya etkiyecek toplam eşdeğer deprem yükü aşağıdaki eşitlikteki (Eşitlik 7) gibi belirlenir.

$$
V_{t}=\frac{S_{D S} W}{R_{a}}
$$

Yukarıdaki eşitlik, toplam eşdeğer deprem yükünün deprem doğrultusundan bağımsı olduğunu göstermektedir. Çünkü eşitlik içerisindeki $S_{D S}$ değeri deprem doğrultusu ile değişmemektedir. Bunun yanında yapının ağırlığı değişmezken deprem yükü azaltma katsayısı da sabit değer alınmaktadır $\left(R_{a}=4\right)$. Bu sebepten ötürü standart deprem hareketi spektrumundan elde edilen maksimum taban kesme kuvveti ile Eşitlik 7'den elde edilen taban kesme kuvveti kıyaslanmıştır.

TBDY 2018 4. bölüme göre doğrusal deprem hesabında kullanılacak eşdeğer deprem yükü yönteminde herhangi bir deprem doğrultusu için toplam eşdeğer deprem yükü aşağıda verilen eşitlikteki (Eşitlik 8) gibi hesaplanır.

$$
V_{t E}^{(X)}=m_{t} S_{a R}\left(T_{p}^{(X)}\right) \geq 0,04 m_{t} I S_{D S} g
$$

Eşitlik 8'deki azaltılmış tasarım spektral ivmesi $\left(\mathrm{S}_{\mathrm{aR}}(\mathrm{T})\right)$, yatay elastik tasarım ivmesi $\left(\mathrm{S}_{\mathrm{ae}}(\mathrm{T})\right)$ ve deprem yükü azaltma katsayısına $\left(\mathrm{R}_{\mathrm{a}}(\mathrm{T})\right)$ göre belirlenmektedir (Eşitlik 9).

$$
S_{a R}(T)=\frac{S_{a e}(T)}{R_{a}(T)}
$$

Eşitlik 9'daki yatay elastik tasarım spektrumu $\left(\mathrm{S}_{\mathrm{ae}}(\mathrm{T})\right)$, yapının doğal titreşim periyodu ile yatay tasarım spektrumu köşe periyotları $\left(\mathrm{T}_{\mathrm{A}}, \mathrm{T}_{\mathrm{B}}\right)$ ve sabit yerdeğiştirme bölgesine geçiş periyodu arasındaki ilişki kullanılarak aşağıdaki eşitliklerdeki (Eşitlik 10, 11, 12 ve 13) gibi hesaplanmaktadır. Yatay elastik tasarım spektrumu ile yapının doğal titreşim periyodu arasındaki ilişki Şekil 4’teki gibi tanımlanmıştır.

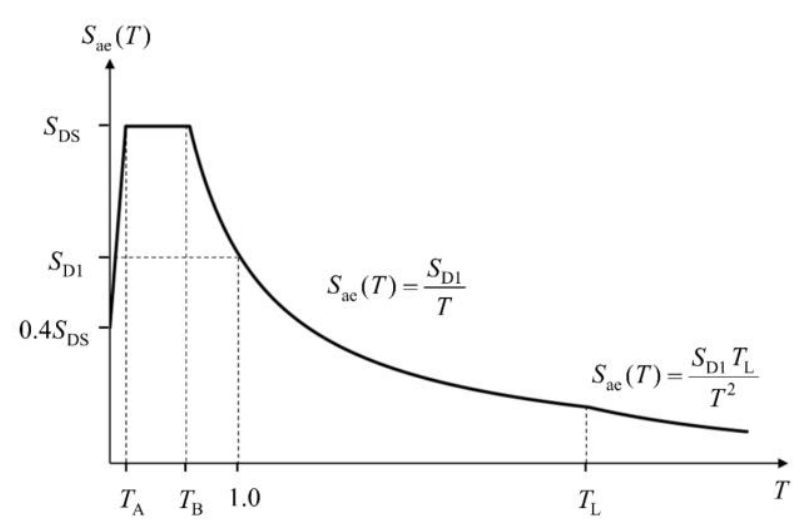

Şekil 4. Yatay elastik tasarım spektrumu [6]

$$
\begin{array}{lr}
S_{a e}(T)=\left(0,4+0,6 \frac{T}{T_{A}}\right) S_{D S} & \left(0 \leq T \leq T_{A}\right) \\
S_{a e}(T)=S_{D S} & \left(T_{A} \leq T \leq T_{B}\right) \\
S_{a e}(T)=\frac{S_{D S}}{T} & \left(T_{B} \leq T \leq T_{L}\right) \\
S_{a e}(T)=\frac{S_{D S} T_{L}}{T^{2}} & \left(T \leq T_{L}\right)
\end{array}
$$

Eşitlik 7 ve 8 arasındaki fark, yapıların üzerine gelecek toplam eşdeğer deprem yükleri arasındaki farkı temsil 
etmekte olup farklı yapı sistemleri, deprem tasarım sınıfları ve yerel zemin sınıfları için yapıya etkiyecek taban kesme kuvvetleri arasındaki temel ilişkiyi oluşturmaktadır.

Bu çalışmada incelenen yapının TBDY 2018'in iki farklı hesap yöntemine göre deprem hesabı yukarıda belirtilen esaslara göre yapılmış ve taban kesme kuvvetleri deprem tasarım sınıfı, yerel zemin sinıfı ve kat sayısı üzerinden değerlendirilmiştir. Standart tasarım ivme spektrumuna göre deprem hesabı TBDY 2018 4. bölümde belirtilen yatay elastik tasarım ivme spektrumu kullanılarak eşdeğer deprem yükü yöntemi ile gerçekleştirilmiştir. TBDY 2018 17. bölümde belirtilen basitleştirilmiş tasarım hesabının deprem yükü hesabı Eşitlik 7'ye göre hesaplanmıştır.

Bu çalışmada taban devirme momentleri, toplam eşdeğer deprem yükünün katlara dağıtılmasıyla hesaplandığı için ve toplam eşdeğer deprem yükü değişiminden birebir etkileneceği için dikkate alınmamıştır. İki hesap yöntemi arasındaki toplam eşdeğer deprem yükü değişimi taban devirme momentleri değişimini temsil edecektir.

\section{BULGULAR}

TBDY 2018'in standart deprem hareket spektrumu kullanılarak yapılan deprem hesabı ile aynı yönetmeliğin 17. bölümünde yer alan basitleştirilmiş tasarım hesabına esas deprem hesabı bu çalışmanın yöntem kısmında belirtilen yapı için gerçekleştirilmiş olup iki hesap yöntemi için yapının taban kesme kuvvetleri karşılaştırılmıştır. Bu çalışmada taban kesme kuvvetleri arasındaki farkları ortaya çıkarabilmek için deprem tehlike sınıfları, yerel zemin sınıfları ve BYS içinde kalacak şekilde belirlenen yapının kat sayıları değişken parametre olarak alınmış ve sonuçlar aşağıda açıklanmıştır. Yukarıda belirlenen parametrelere göre standart ve basitleştirilmiş hesaptan elde edilen taban kesme kuvveti değerleri Tablo 6'da verilmiştir.

\subsection{Yerel Zemin Sınıfının Taban Kesme Kuvveti Değişimine Etkisi}

Şekil 5 ve 6'da farklı yerel zemin sınıfları için basitleştirilmiş tasarım esaslarına göre belirlenen taban kesme kuvvetlerinin standart deprem hareketi spektrumundan elde edilen taban kesme kuvvetlerine göre değişimi yüzde olarak verilmiştir. Deprem tasarım sınıfı 1 ve 2 için farklı yerel zemin sınıflarının taban kesme kuvvetindeki bu değişime etkisi Şekil 5'te verilmiştir. Tüm kat seviyeleri için $\mathrm{ZA}, \mathrm{ZB}, \mathrm{ZC}, \mathrm{ZD}$ ve ZE zemin sınıflarında, basitleştirilmiş hesaba göre taban kesme kuvvetlerinde standart deprem hareketi spektrumundan elde edilen taban kesme kuvvetlerine göre -\%11 ile bir azalma ve $+\% 92$ bir artış arasında değişimin olduğu görülmüşsür. Bütün kat seviyeleri göz önüne alındığında taban kesme kuvvetindeki en fazla artışın meydana geldiği zemin sınıfı ZB'dir. ZD zemin sınıfında 3 katlı yapı için ve ZE zemin sınıfında ise 3 ve 4 katlı yapıların taban kesme kuvvetlerinde standart hesaba göre azalma meydana gelmiştir. Farklı zemin sınıflarına göre elde edilen taban kesme kuvvetlerindeki artış, basitleştirilmiş hesabın standart hesaba göre yapının daha fazla deprem kuvvetleri alacağını göz önüne almaktadır.

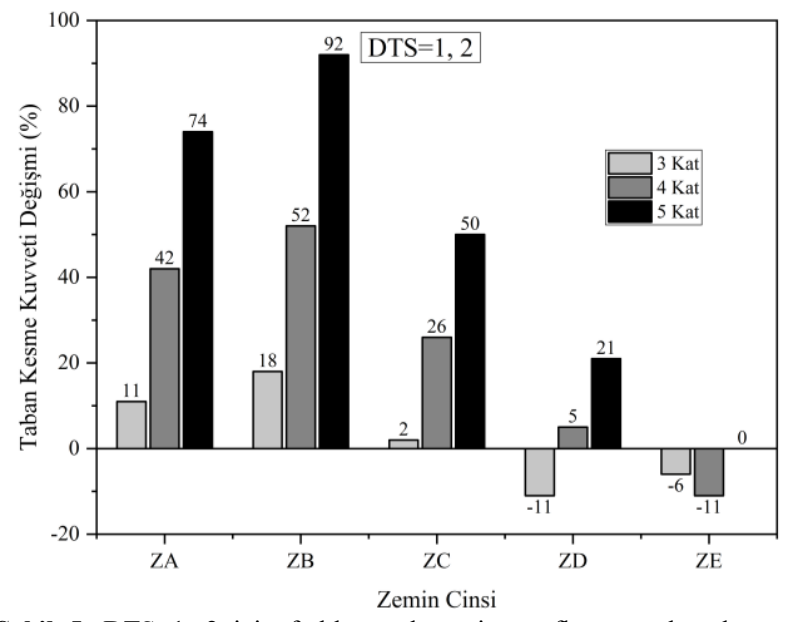

Sekil 5. DTS=1, 2 için farklı yerel zemin sınıflarının taban kesme kuvvetine etkisi

Tablo 6. Standart ve basitleştirilmiş hesaptan elde edilen taban kesme kuvveti değerleri

\begin{tabular}{|c|c|c|c|c|c|c|c|}
\hline \multirow{3}{*}{$\begin{array}{l}\text { Deprem } \\
\text { Tasarım } \\
\text { Sinıfları }\end{array}$} & \multirow{3}{*}{$\begin{array}{c}\text { Yerel } \\
\text { Zemin } \\
\text { Sinıfları }\end{array}$} & \multicolumn{2}{|c|}{5 Katlı Yapı } & \multicolumn{2}{|c|}{4 Katlı Yapı } & \multicolumn{2}{|c|}{3 Katlı Yapı } \\
\hline & & $\begin{array}{c}\text { Standart } \\
\text { Hesap }\end{array}$ & $\begin{array}{c}\text { Basitleştirilmiş } \\
\text { Hesap }\end{array}$ & $\begin{array}{c}\text { Standart } \\
\text { Hesap }\end{array}$ & $\begin{array}{c}\text { Basitleştirilmiş } \\
\text { Hesap }\end{array}$ & $\begin{array}{l}\text { Standart } \\
\text { Hesap }\end{array}$ & $\begin{array}{c}\text { Basitleştirilmiş } \\
\text { Hesap }\end{array}$ \\
\hline & & $\begin{array}{c}\text { Taban } \\
\text { Kesme } \\
\text { Kuvveti }(k N)\end{array}$ & $\begin{array}{l}\text { Taban Kesme } \\
\text { Kuvveti }(\mathbf{k N})\end{array}$ & $\begin{array}{c}\text { Taban } \\
\text { Kesme } \\
\text { Kuvveti }(k N)\end{array}$ & $\begin{array}{l}\text { Taban Kesme } \\
\text { Kuvveti }(\mathbf{k N})\end{array}$ & $\begin{array}{c}\text { Taban } \\
\text { Kesme } \\
\text { Kuvveti }(k \mathbf{N})\end{array}$ & $\begin{array}{l}\text { Taban Kesme } \\
\text { Kuvveti (kN) }\end{array}$ \\
\hline \multirow{5}{*}{$\mathrm{DTS}=1,2$} & ZA & 2446,39 & 4240,70 & 2375,62 & 3362,96 & 2298,03 & 2557,36 \\
\hline & ZB & 2505,54 & 4770,37 & 2499,01 & 3783,00 & 2451,57 & 2876,78 \\
\hline & $\mathrm{ZC}$ & 4249,14 & 6359,39 & 4012,58 & 5043,13 & 3778,94 & 3835,05 \\
\hline & ZD & 4396,73 & 5300,04 & 4019,27 & 4203,05 & 3613,35 & 3196,21 \\
\hline & $\mathrm{ZE}$ & 4261,61 & 4240,70 & 3765,02 & 3362,96 & 2719,61 & 2557,36 \\
\hline \multirow{5}{*}{$\mathrm{DTS}=3,4$} & ZA & 358,60 & 523,05 & 337,43 & 414,79 & 316,11 & 315,43 \\
\hline & ZB & 377,20 & 589,26 & 358,25 & 467,30 & 340,32 & 355,36 \\
\hline & $\mathrm{ZC}$ & 631,49 & 850,79 & 587,43 & 674,69 & 541,21 & 513,07 \\
\hline & ZD & 888,80 & 1049,42 & 809,71 & 832,21 & 724,52 & 632,85 \\
\hline & $\mathrm{ZE}$ & 1427,75 & 1572,47 & 1285,23 & 1247,00 & 1085,36 & 948,28 \\
\hline
\end{tabular}


Sekil 6, DTS 3 ve 4 için iki farklı hesap yönteminden elde edilen taban kesme kuvvetlerinin değişimi göstermektedir. DTS 1 ve 2'ye benzer bir şekilde basitleştirilmiş hesaptan elde edilen taban kesme kuvvetleri standart hesaba göre daha yüksek değerler almakta ve en fazla artışın görüldüğü zemin sınıfı yine ZB olmaktadır. Taban kesme kuvvetindeki en büyük değişim \%57'lik değeriyle ZB yerel zemin sınıfındaki 5 katlı yapıda gerçekleşmiştir. Bu da göstermektedir ki basitleştirilmiş hesaptan elde edilen taban kesme kuvveti standart hesaptan elde edilen taban kesme kuvvetinin yaklaşık 1,5 katı değerine ulaşmaktadır. 3 katlı yapı için $\mathrm{ZA}, \mathrm{ZB}$ ve ZC zemin sınıflarında basitleştirilmiş ve standart hesap sonucunda ortaya çıkan taban kesme kuvvetlerinin yakın değerler elde etmiştir. DTS 1 ve 2'ye oranla taban kesme kuvvetindeki değişim daha düşük seviyededir.

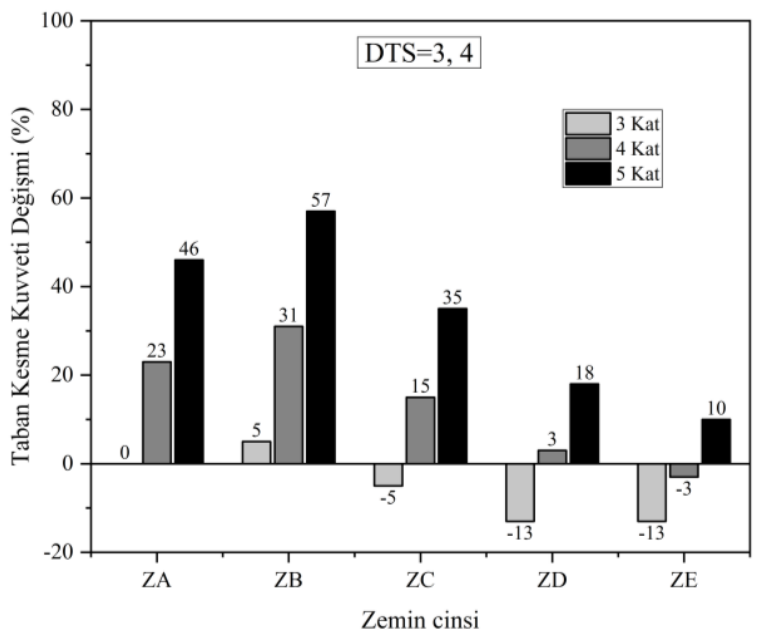

Sekil 6. DTS $=3,4$ için farklı yerel zemin sınıflarının taban kesme kuvvetine etkisi

$\mathrm{Bu}$ çalısmada ise, TBDY 2018'e göre yerel zemin sınıfları hem standart hem de basitleştirilmiş deprem hesabından elde edilen taban kesme kuvvetlerini etkilediği ortaya çıkmıştır (Tablo 5). Şekil 5 ve 6 , basitleștirilmis hesaptan elde edilen taban kesme kuvvetlerinin standart deprem hesabına göre yerel zemin sınıflarından ciddi anlamda etkilendiğini ortaya koymuştur. Bütün deprem tasarım sınıflarında en fazla değişimin görüldüğü zemin sınıfi $\mathrm{ZB}$ olarak belirlenmiştir. İki farklı hesap yöntemi incelendiğinde, deprem tasarım sinifi 1 ve 2 olan yapıların 3 ve 4 olan yapılara göre taban kesme kuvveti değişimi daha fazla görülmektedir.

\subsection{Yapının Kat Sayısının Taban Kesme Kuvveti Değişimine Etkisi}

Yapının kat sayısının, standart deprem hesabına göre basitleştirilmiş hesaptan elde edilen taban kesme kuvvetlerine etkisi Şekil 7 ve 8'de verilmiştir. Aşağıdaki grafikler incelendiğinde bütün zemin sınıfları için, yapının kat sayısının artmasıyla basitleştirilmiş deprem hesabı ile standart deprem hesabından elde edilen taban kesme kuvvetleri arasındaki fark artış göstermiştir.
Şekil 7, taban kesme kuvvetindeki en büyük değișimin kat sayısı 5 olan yapılarda en düşük değişimin ise kat sayısı 3 olan yapılarda gerçekleştiğini göstermektedir. Taban kesme kuvvetindeki maksimum değişim, ZB yerel zemin sınıfında inşa edilen 5 katlı yapıda \%92'lik değeriyle elde edilmiștir. Daha düşük kat seviyelerinde zemin durumu kötüleştikçe daha düşük taban kesme kuvvetleri elde edilmektedir (ZD ve ZE zemin sinıfinda inşa edilen 3 katlı yapı ve ZE zemin sınıfında inşa edilen 4 katll yap1).

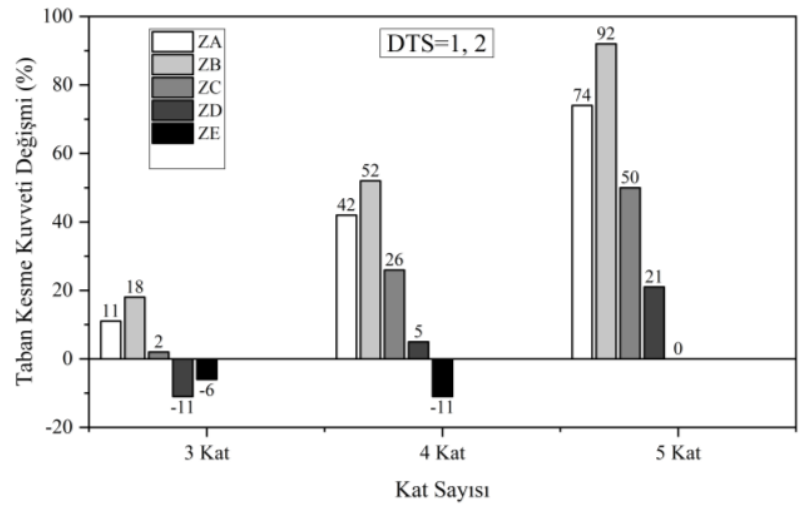

Sekil 7. DTS=1, 2 için yapının kat sayılarının taban kesme kuvvetine etkisi

Deprem tasarım sınıfı 3 veya 4 için, yapının kat sayılarının artışıla standart hesaba göre taban kesme kuvvetindeki değişim artmaktadır (Şekil 8). Taban kesme kuvvetindeki en büyük değişim yine 5 katlı yapıda elde edilmiștir. 3 katlı yapı için ZA ve ZB zemin sinıflarında standart hesaptan elde edilen taban kesme kuvveti değerleri basitleştirilmiş hesaba göre daha yakın çıkmaktadır.

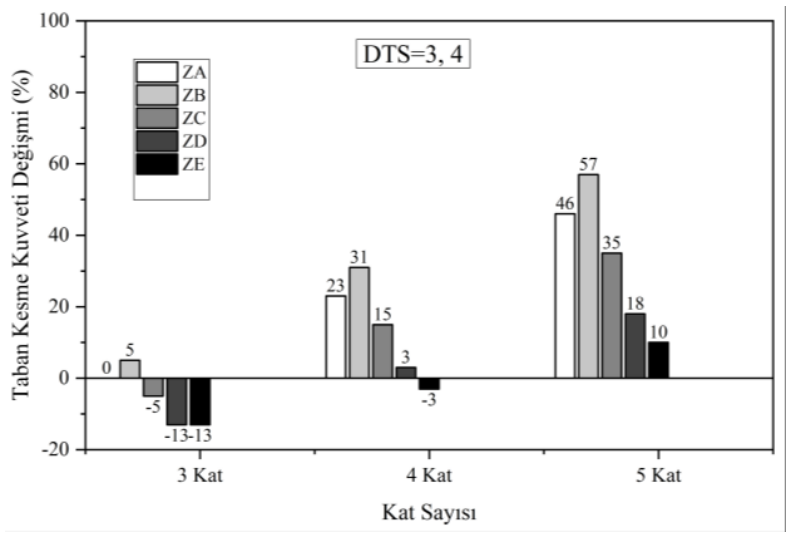

Şekil 8. DTS=3, 4 için yapının kat sayılarının taban kesme kuvvetine etkisi

$\mathrm{Bu}$ çalışmada, her iki hesap yöntemi ayrı ayrı incelendiğinde yapının kat sayılarının artması genel olarak taban kesme kuvveti değerlerini düşürmüş̧ür (Tablo 5). Şekil 7 ve 8 incelendiğinde, yapının kat say1ları düştükçe standart hesaptan ve basitleştirilmiş hesaptan elde edilen taban kesme kuvveti değerleri arasındaki farkın azaldığı anlaşılmaktadır. Standart hesaba göre basitleștirilmiş hesaptan elde edilen taban kesme kuvvetlerinin kat sayısı arttıkça yükseldiği tespit edilmiştir. Yerel zemin sınıfları gözetilerek yapılacak incelemede taban kesme kuvvetindeki değişimin en fazla meydana geldiği zemin sınıfının ZB olduğu söylenebilir. 


\subsection{Deprem Tasarım Sinıflarının Taban Kesme Kuvveti Değișimine Etkisi}

Bilindiği üzere deprem bölgesi kavramının yerini TBDY 2018 ile deprem tasarım sınıfı almış ve bundan önce yapılan bazı çalışmalarda deprem bölgelerinin yapıların yatay yüklerine etkisi incelenmiştir [20]. Bu çalışmada, farklı deprem tasarım sınıfları için basitleştirilmiş tasarım esaslarına göre belirlenen taban kesme kuvvetlerinin standart deprem hareketi spektrumundan elde edilen taban kesme kuvvetlerine göre değişimi incelenmiş ve bu değişim Şekil 9, 10 ve 11 'da yüzde olarak verilmiștir.

Şekil 9, 5 katlı yapı için deprem tasarım sınıfının taban kesme kuvvetinde meydana getirdiği değişimi göstermektedir. Aşağıdaki grafik incelendiğinde deprem tasarım sınıfı yükseldikçe iki farklı hesap yönteminden elde edilen taban kesme kuvveti değerlerinin arasındaki farkın azaldığı görülmektedir. ZA, ZB, ZC ve ZD yerel zemin sinıflarında deprem tasarım sinıfinın 1 veya 2 'den 3 veya 4'e yükselmesi basitleştirilmiş hesap ile standart hesaptan elde edilen taban kesme kuvvetleri arasındaki farkı azaltırken, ZE yerel zemin sınıfında bir miktar artış meydana gelmiştir.

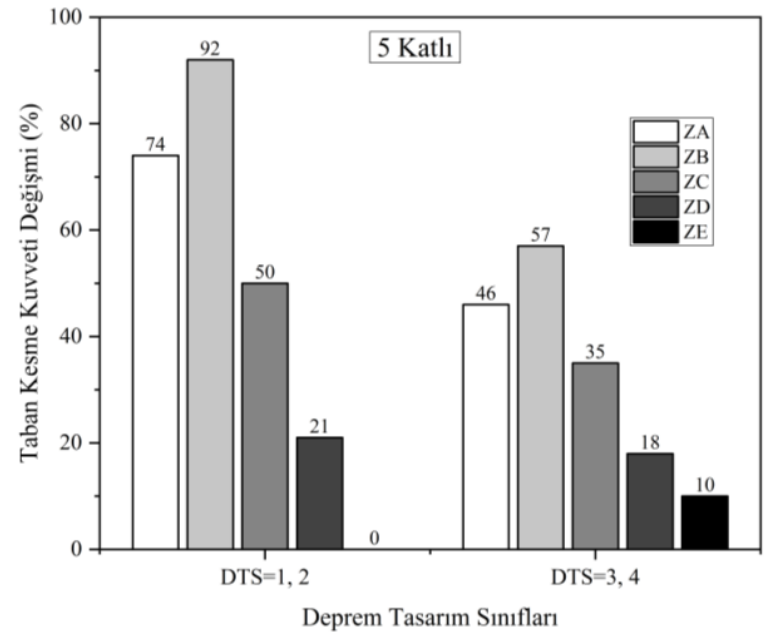

Sekil 9. 5 katlı yapı için deprem tasarım sınıfının taban kesme kuvvetine etkisi

5 katlı yapıda olduğu gibi iki farklı hesap yöntemi için deprem tasarım sınıfının taban kesme kuvveti değişimi üzerindeki etkisi 3 ve 4 katlı yapılar için yaklaşık benzer olduğu ortaya çıkmıştır (Şekil 10 ve 11). Zemin durumu nispeten daha iyi olan 3,4 ve 5 katlı yapının deprem tasarım sınıfı arttıkça iki farklı hesap yönteminden elde edilen taban kesme kuvveti değerleri arasındaki fark azalmaktadır. 3 katlı yapıda zemin durumu kötüleştikçe her iki deprem tasarım sınıfı için basitleştirilmiş hesaptan elde edilen taban kesme kuvvetleri standart hesaba daha düşük değerler elde etmiștir. Bu durum 4 katlı yapıda sadece ZE zemin sinıfinda meydana gelmiştir. Burada dikkat edilmesi gereken husus, genel olarak kat sayısı düștükçe deprem tasarım sınıfinın taban kesme kuvveti değerleri üzerindeki etkisinin azalmasıdır.

Deprem açısından daha riskli bölgelerde yapılacak yapıların basitleştirilmiş hesabının standart hesaba göre daha fazla taban kesme kuvveti değerlerine sahip olduğu ortaya çımaktadır. Bütün değișim değerleri incelendiğinde TBDY 17. bölümdeki tasarım esaslarının bu çalışmadaki 4 ve 5 katlı yapılar için zemin durumunun nispeten daha kötü olduğu durumlarda daha yaklaşık değerler verdiği ortaya çıkmıştır. Bunun yanında kat sayısının düsmesi de standart hesaba göre nispeten daha yaklaşık sonuçlar verdiği söylenebilir.

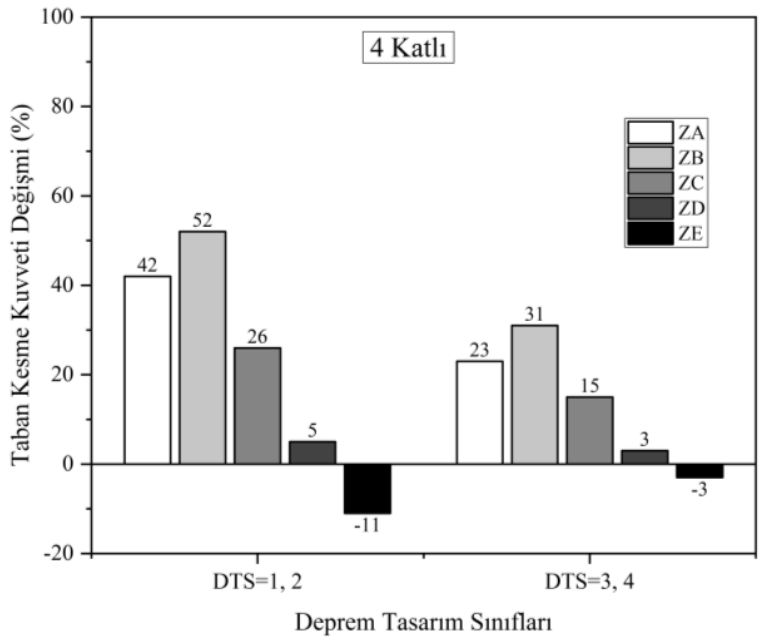

Sekil 10. 4 katlı yapı için deprem tasarım sınıfının taban kesme kuvvetine etkisi

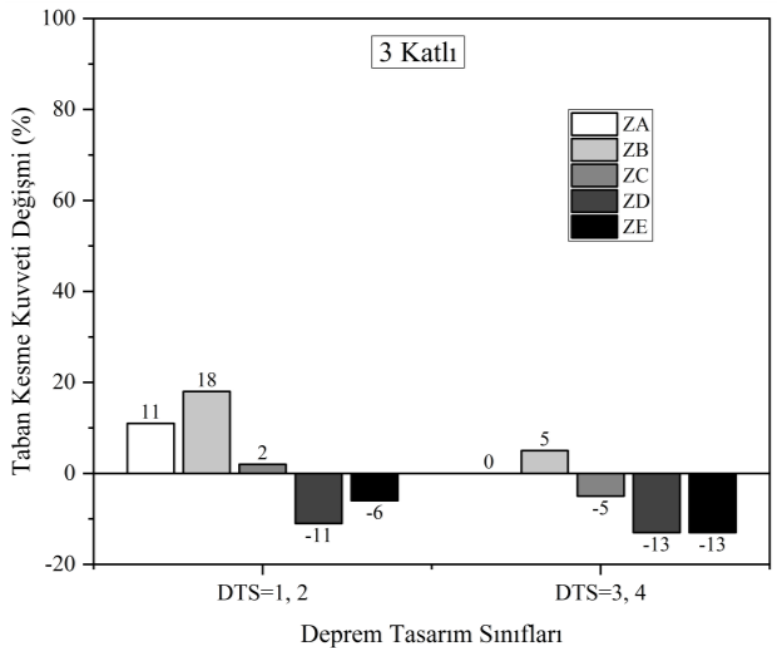

Sekil 11. 3 katlı yapı için deprem tasarım sınıfının taban kesme kuvvetine etkisi

\section{SONUC}

Bu çalışmada, TBDY 2018'de yer alan standart deprem tehlike spektrumuna ve aynı yönetmeliğin 17. bölümünde yer alan düzenli yerinde dökme betonarme binalar için basitleştirilmiş tasarım kurallarına göre hesaplanan toplam eşdeğer deprem yükleri hesaplanmış ve taban kesme kuvvetleri incelenmiştir. İki hesap yöntemi arasındaki fark1 inceleyebilmek için deprem tasarım sinıfi, yerel zemin sinıfi ve yapının kat sayısı parametre olarak belirlenmiş ve elde edilen sonuçlar aşağıda maddeler halinde açıklanmıştır.

- TBDY 2018 17. Bölümde beton ve donatı sinıflarında önceki bölümlerden farklı olarak sınırlandırma getirilmiştir. 
- TBDY 2018 17. bölüm, toplam eşdeğer deprem yükü yöntemi için basitleştirilmiş bir denklem sunmaktadır. 17. Bölümde verilen denkleme göre yapının taban kesme kuvveti $S_{D S}$ 'ye göre değişmektedir ve taşıyıcı sistem davranış katsayısı basitleştirilmiş hesabın kullanılacağı yapılarda sabit olarak alınacağı görülmüsstür.

- Genel olarak basitleştirilmiş deprem hesabından elde edilen taban kesme kuvveti değerleri standart deprem hesabına göre yüksek değerler almakta ve seçilen parametreler için yaklaşık 1,5 katına kadar çıkabilmektedir.

- Yerel zemin sinıflarının iki hesap yönteminden elde edilen taban kesme kuvveti değişimini etkilediği tespit edilmiştir. Genel olarak sağlam zeminden kötü zemine geçildikçe iki hesap yönteminden elde edilen taban kesme kuvveti değerleri birbirine yaklaşmaktadır. Basitleştirilmiş tasarım kuralları taban kesme kuvvetleri açısında kötü zeminlerde ya standart deprem hesabına yakın ya da daha düşük değerler vermektedir.

- Yerel zemin sınıflarının yanında yapının kat sayılarının da hesap yöntemleri arasında deprem açısından fark oluşturduğu gözlenmiştir. Yapının kat sayıları arttıkça, basitleştirilmiş hesap ile standart hesaptan elde edilen taban kesme kuvveti değerleri arasındaki fark ta artmaktadır.

- Deprem tasarım sınıfları 1'den 4'e doğru değiştikçe basitleştirilmiş deprem hesabı ile standart deprem hesabı arasındaki fark azalmaktadır.

\section{KAYNAKLAR}

[1] Demirtaş R, Kayabalı K. Deprem Jeolojisi. Gazi Kitabevi; 2006.

[2] Nemutlu ÖF, Sarı A. Yeni Türk Deprem Yönetmeliği ile Amerikan Deprem Yönetmeliklerinin Deprem Hesapları Açısından Karşılaştırılması. 5. Uluslararası Deprem Mühendisliği ve Sismoloji Konferansı, 5. ICEES. Ankara; 2019. p. 1-13.

[3] Keskin E, Bozdoğan KB. 2007 ve 2018 Deprem Yönetmeliklerinin Kırklareli İli Özelinde Değerlendirilmesi. Kırklareli University Journal of Engineering and Science. 2018; 4:74-90.

[4] Alyamaç KE, Erdoğan AS. Geçmişten Günümüze Afet Yönetmelikleri ve Uygulamada Karşılaşılan Tasarım Hataları. Deprem Sempozyumu. Kocaeli; 2005. p. 707-715.

[5] Kemaloğlu M. Türkiye'de Afet Yönetiminin Tarihi ve Yasal Gelişimi. Akademik Bakış Dergisi. 2015; 52:126-147.

[6] Anonim. Türkiye Bina Deprem Yönetmeliği. 18 Mart 2018 Tarih ve 30364 Sayılı Resmi Gazete. 2018.

[7] Anonim. Deprem Bölgelerinde Yapılacak Binalar Hakkında Yönetmelik. 3 Mayıs 2007 Tarih ve 26511 Sayılı Resmi Gazete. 2007.

[8] Anonim. Afet Bölgelerinde Yapılacak Yapılar Hakkında Yönetmelik. 2 Temmuz 1998 Tarih ve 23390 Sayılı Resmi Gazete. 1998.

[9] Tunç G, Tanfener T. 2007 ve 2016 Türkiye Bina Deprem Yönetmeliklerinin Örneklerle Mukayesesi.
3. Ulus. Yapı Kongresi ve Sergisi. Ankara; 2016. p. $1-14$.

[10] Akkar S, Azak TE, Çan T, Çeken U, Demircioğlu $\mathrm{MB}$, Duman T, ve ark. Güncellenmiş Türkiye Deprem Tehlike Haritası ve Mühendislik Uygulamalarına Etkisi. Uluslararası Katılımlı 72. Türkiye Jeoloji Kurultayı. Ankara; 2019. p. 23-24.

[11] Afet ve Acil Durum Yönetimi Başkanlığı. Türkiye Deprem Tehlike Haritası. Erişim tarihi: 01.04.2020. https://deprem.afad.gov.tr/deprem-tehlike-haritasi.

[12] Afet ve Acil Durum Yönetimi Başkanlığı. Türkiye Deprem Tehlike Haritaları İnteraktif Web Uygulaması. Erişim tarihi: 01.04.2020. https://tdth.afad.gov.tr/TDTH/main.xhtml.

[13] Uzun M, Korkmaz HH. Deprem Bölgesindeki Bazı Ülkelerde Eşdeğer Deprem Yükü Metodunun Karşılaştırılması. Selçuk Üniversitesi Mühendislik Bilim ve Teknoloji Dergisi. 2019; 7:189-212.

[14] Nemutlu ÖF, Sarı A. Comparison of Turkish Earthquake Code in 2007 With Turkish Earthquake Code in 2018. International Engineering and Natural Sciences Conference, IENSC 2018. Diyarbakır; 2018. p. 14-25.

[15] Öztürk M. 2018 Türkiye Bina Deprem Yönetmeliği ve Türkiye Deprem Tehlike Haritasi İle İlgili İç Anadolu Bölgesi Bazında Bir Değerlendirme. Selçuk-Teknik Dergisi. 2018; 17: 31-42.

[16] Koçer M, Nakipoğlu A, Öztürk B, Al-Hagri MG, Arslan MH. Deprem Kuvvetine Esas Spektral İvme Değerlerinin TBDY 2018 ve TDY 2007'ye Göre Karşılaştırılması. Selçuk-Teknik Dergisi. 2018; 17: 43-58.

[17] Afacan KB, Güler E. Yeni Deprem Yönetmeliği Performansının Zemin Büyütme Analizi ile Belirlenmesi. 5. International Conference on Earthquake Engineering and Seismology, 5. ICEES. Ankara; 2019. p. 1-11.

[18] Boru EO. Farklı Zemin Sinıflarının Bina Deprem Performansına Etkisi. 3. International Symposium on Innovative Technologies in Engineering and Science, ISITES 2015. 2015. p. 1865-1872.

[19] Nemutlu ÖF. 2007-2018 Türk Deprem Yönetmeliklerinin ve Amerikan Deprem Yönetmeliğinin Deprem Hesapları Açısından Karşılaştırılması. İstanbul: İstanbul Teknik Üniversitesi Fen Bilimleri Enstitüsü; 2019.

[20] Muratoğlu Ö, Özkan Ö. Zemin Sınıfları ve Deprem Bölgelerinin Bina Yatay Yüklerine Etkisi. Deprem Sempozyumu. Kocaeli; 2005. p. 1097-1104. 